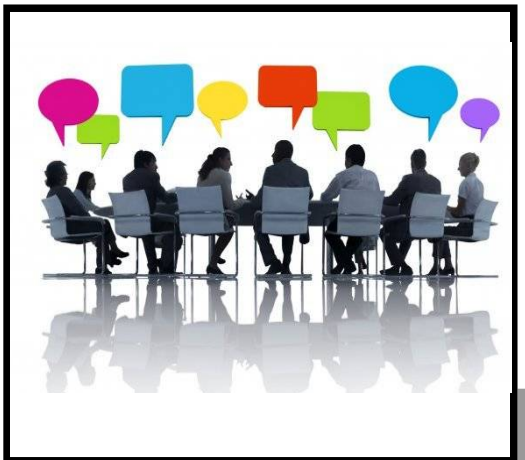

УПРАВЛIHНЯ ОСВITOЮ

УДК 378.091.12:33.025.3

Анна ГЕЛЕШ, кандидат історичних наук, заступник начальника навчально-методичного відділу

Національного університету "Львівська політехніка"

\title{
КАДРОВЕ ЗАБЕЗПЕЧЕННЯ ЗАПОЧАТКУВАННЯ ТА ПРОВАДЖЕННЯ ОСВІТНЬОЇ ДІЯЛЬНОСТІ У СФЕРІ ВИЩОЇ ОСВІТИ УКРАЇНИ
}

Anna HELESH, PhD, Candidate of Historical Sciences, Deputy Head of the teaching and methodical department National University "Lviv Polytechnic"

\section{PERSONAL PROVIDED FOR PREVENTION AND PROTECTION OF EDUCATIONAL ACTIVITIES IN THE HIGHER EDUCATION OF UKRAINE}

\begin{abstract}
У статті представлено нормативно-правові документи, що регулюють сучасний порядок процедури ліцензування у сфері вищої освіти України як виду господарської діяльності. Обгрунтовано зміст поняття процедури ліцензування освітньої діяльності та окремих їі складових. Охарактеризовано освітні послуги, що підлягають ліцензування у сфері вищої освіти. Автором систематизовано та упорядковано кадрові вимоги щодо започаткування та провадження освітньої діяльності у процедурі ліцензування у сфері вищої освіти. Також на основі власного досвіду узагальнено окремі дискусійні питання щодо кадрового забезпечення, виявлені під час проходження процедури ліцензування освітньої діяльності у сфері вищої освіти.
\end{abstract}

Ключові слова: процедура ліцензування, кадрові вимоги, освітня діяльність, заклад вищої освіти.

Summary. The article presents normative and legal documents regulating the modern procedure of licensing in the field of higher

(c) А. Гелеш education of Ukraine, as a type of economic activity. The content of the concept of the licensing process of educational activity and its separate components is substantiated. Educational services subject to licensing in the field of higher education are described. The author systematized and arranged staffing requirements for the initiation and implementation of educational activities in the licensing process in the field of higher education. As well, on the basis of their own experience, there are generalized separate discussion questions regarding staffing, found during the licensing process of educational activities in the field of higher education.

Key words: licensing procedure, personnel requirements, educational activity, institution of higher education.

Мета: систематизувати та впорядкувати кадрові вимоги щодо започаткування і провадження освітньої діяльності у процедурі ліцензування у сфері вищої освіти; узагальнити досвід, що передбачає виявлення окремих порушень у кадровому забезпеченні під час проходження процедури ліцензування освітньої діяль- ності у сфері вищої освіти.

Постановка проблеми в загальному вигляді. У сфері вищої освіти України, що сформувалася за останні понад двадцять років, кожен заклад вищої освіти (3ВО) для того, щоб отримати ліцензію на надання освітніх послуг та можливість зробити набір на навчання, повинен проходити процедуру ліцензування. Система ліцензування в Україні $є$ одним з головних інструментів державної системи забезпечення якості вищої освіти, який до сьогодні практично нівелював право на автономність та самостійність $3 \mathrm{BO}$ в освітній діяльності. Проведення процедури ліцензування освітньої діяльності бачиться випробуванням для будь-якого закладу, адже заклад освіти будь-якого рівня та форми власності стикається 3 низкою проблем як зовнішніх (на рівні органів управління, ліцензування та інших), так і внутрішніх (організація, час, методика).

Закон України "Про вищу освіту" визначає ліцензування як процедуру визнання спроможності закладу вищої освіти певного типу розпочати освітню діяльність, пов'язану із здобуттям вищої освіти та кваліфікації, 
відповідно до вимог стандартів вищої освіти, а також до Ліцензійних вимог щодо кадрового, матеріально-технічного, навчально-методичного та інформаційного забезпечення [3-5].

Загалом ліцензійні вимоги щодо забезпечення започаткування та провадження освітньої діяльності у сфері вищої освіти класифіковано за такими критеріями, як: кадрові, технологічні, організаційні [1]. Тому актуальним є питання кадрового забезпечення започаткування та провадження освітньої діяльності ЗВО, адже кадрове забезпечення навчального процесу - один із головних чинників, що забезпечує якість вищої освіти в Україні.

Аналіз досліджень і публікацій. У зв'язку з постійними змінами в чинному законодавстві України щодо питань ліцензування освітньої діяльності ЗВО існує небагато наукових публікацій за темою дослідження. Окремі аспекти щодо кадрових вимог у процедурі ліцензування та ліцензування освітньої діяльності у своїх працях розкривали: А. Шевцов, О. Шаров, Н. Губерська, Ю. Фролов, І. Гомова та інші. Зазначимо, що аналіз реалізації акредитаційних вимог у сфері кадрового забезпечення навчального процесу зробив у своїй доповіді В. Рябчій [7]. Проте питання кадрового забезпечення щодо започаткування та провадження освітньої діяльності у сфері вищої освіти під час проходження процедури ліцензування висвітлювалося неповною мірою і потребує детального обгрунтування та упорядкування.

Основними джерелами для написання цієї статті стали нормативні документи, що регулюють процедуру ліцензування освітньої діяльності у сфері вищої освіти в Україні сьогодні [2-5], а також рекомендації та консультації з МОН України, власні спостереження, отримані під час роботи 3 документами у процесі формування ліцензійних справ для започаткування та провадження освітньої діяльності Національного університету "Львівська політехніка".

Виклад основного матеріалу дослідження. Ключовими нормативноправовими документами, що регулюють сучасний порядок процедури ліцензування у сфері вищої освіти України як виду господарської діяльності, є: Закон України "Про вищу освіту", "Про ліцензування видів господарської діяльності", "Про адміністративні послуги", постанова
Кабінету Міністрів України від 10.05.2018 p. № 347 "Про внесення змін до постанови Кабінету Міністрів України від 30.12.2015 р. № 1187".

У першу чергу, вважаємо за необхідне зупинитися на визначенні змісту процедури ліцензування освітньої діяльності та окремих її складових. Так, відповідно до Закону України "Про ліцензування видів господарської діяльності", ліцензування це засіб державного регулювання провадження видів господарської діяльності, що підлягають ліцензуванню, спрямований на забезпечення реалізації єдиної державної політики у сфері ліцензування, захист економічних і соціальних інтересів держави, суспільства та окремих споживачів [4]. Цей документ встановлює обов'язковість погоджених спеціально уповноваженим органом 3 питань ліцензування і затверджених Кабінетом Міністрів України чинних Ліцензійних умов.

Згідно з нормами чинного законодавства України зміст процедури ліцензування передбачає:

видачу, переоформлення та анулювання ліцензій на освітню діяльність 3ВО;

видачу дублікатів ліцензій на освітню діяльність ЗВО;

ведення ліцензійних справ та ліцензійних реєстрів;

контроль за додержанням ліцензіатами чинних Ліцензійних умов;

видачу розпоряджень про усунення порушень чинних Ліцензійних умов;

видачу розпоряджень про усунення порушень законодавства у даній сфері.

Органом, що забезпечує здійснення процедури ліцензування та контролює виконання чинних Ліцензійних вимог, виступає Міністерство освіти і науки України.

До закладів вищої освіти, котрі мають право здійснювати процедури ліцензування освітніх послуг, необхідно віднести: заклади вищої освіти, наукові установи, що здійснють навчання здобувачів вищої освіти на другому (магістерському) та/або третьому (освітньо-науковому/освітньотворчому) рівнях вищої освіти, заклади післядипломної освіти, а також заклади фахової передвищої освіти. У сфері вищої освіти ліцензуванню підлягає діяльність 3 надання таких освітніх послуг, як: розширення провадження (започаткування та провадження, збільшення ліцензованого об- сягу), звуження провадження (припинення провадження частини освітньої діяльності та зменшення ліцензованого обсягу) освітньої діяльності, а також підвищення кваліфікації, перепідготовка, стажування та інше (рис. 1).

Відповідно до чинних Ліцензійних умов кадрові вимоги щодо забезпечення започаткування та провадження освітньої діяльності для закладів вищої освіти набирали чинності 31 вересня 2018 року [5]. До зазначеного терміну кадрове забезпечення освітньої діяльності здійснювалося згідно з Ліцензійними умовами провадження освітньої діяльності, затвердженими постановою Кабінету Міністрів України від 30.12.2015 р. № 1187 [6]. Кадрові вимоги щодо забезпечення започаткування та провадження освітньої діяльності у сфері вищої освіти є принципово важливими у процесі ліцензування. Так, кадрове забезпечення відповідної спеціальності складається 3 наявності проектної групи - для започаткування освітньої діяльності та групи забезпечення - для провадження освітньої діяльності 3ВО (рис. 2).

Проектна група - це затверджена наказом керівника освітнього закладу, група педагогічних, науково-педагогічних та/або наукових працівників, які відповідають за започаткування освітньої діяльності за спеціальністю на певному рівні вищої освіти і відповідають кваліфікаційним вимогам, визначеним чинними Ліцензійними умовами [5].

У сфері вищої освіти проектна група повинна складатися 3 науковопедагогічних або наукових працівників, які працюють у ЗВО за основним місцем роботи та мають кваліфікацію відповідно до спеціальності і не входять (входили) до жодної проектної групи такого або іншого закладу вищої освіти в поточному семестрі (крім проектної групи з цісї ж спеціальності в даному навчальному закладі). Зазначимо, що для отримання ліцензії з правом навчання іноземців та осіб без громадянства один із членів проектної групи повинен володіти англійською мовою на рівні В2 за Загальноєвропейськими рекомендаціями 3 мовної освіти або кваліфікаційними документами (диплом про вищу освіту, науковий ступінь), що пов'язані з використанням зазначеної мови. Такі вимоги вводяться в дію з 1 січня 2020 року [5].

Керівником проектної групи при- 


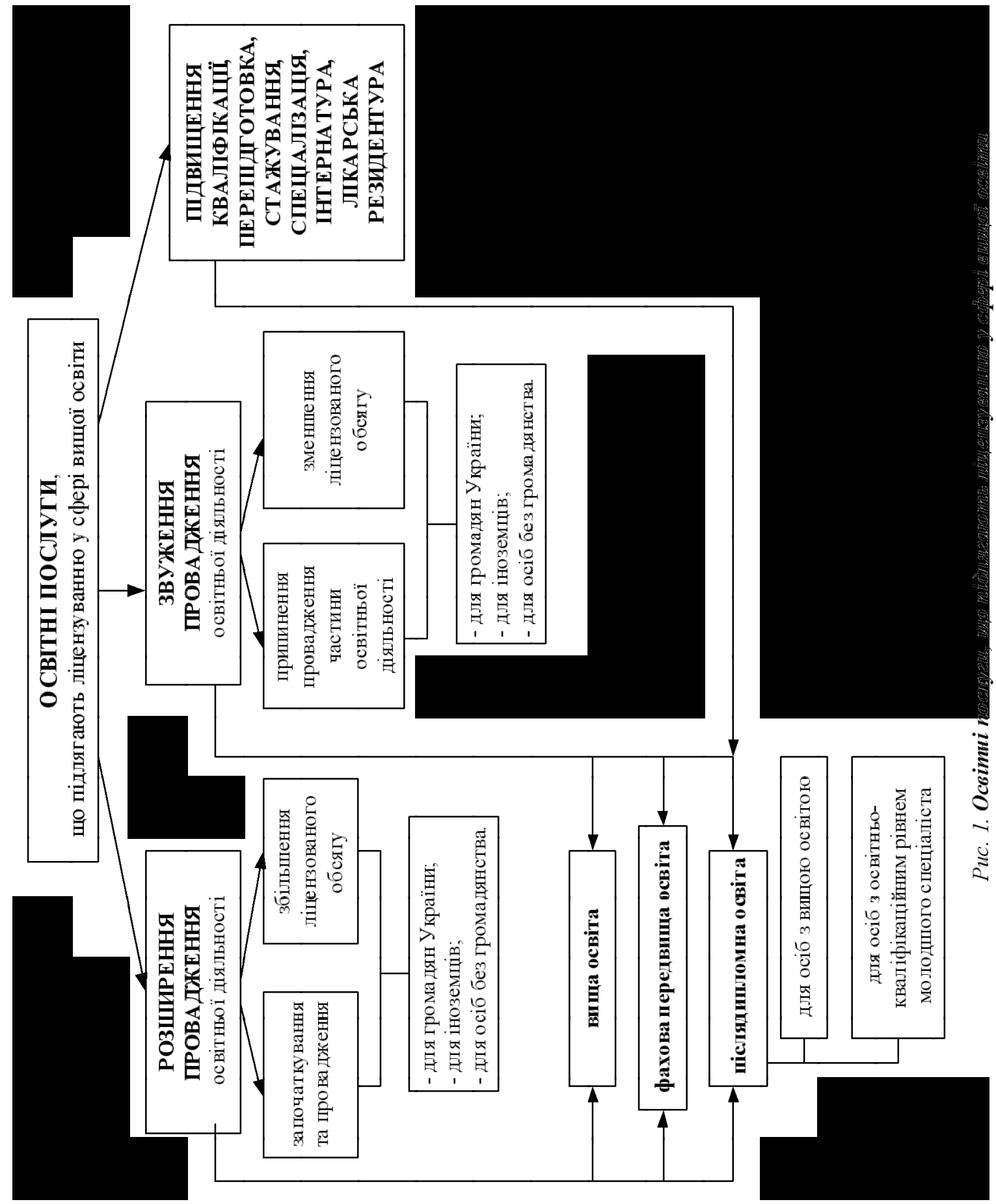




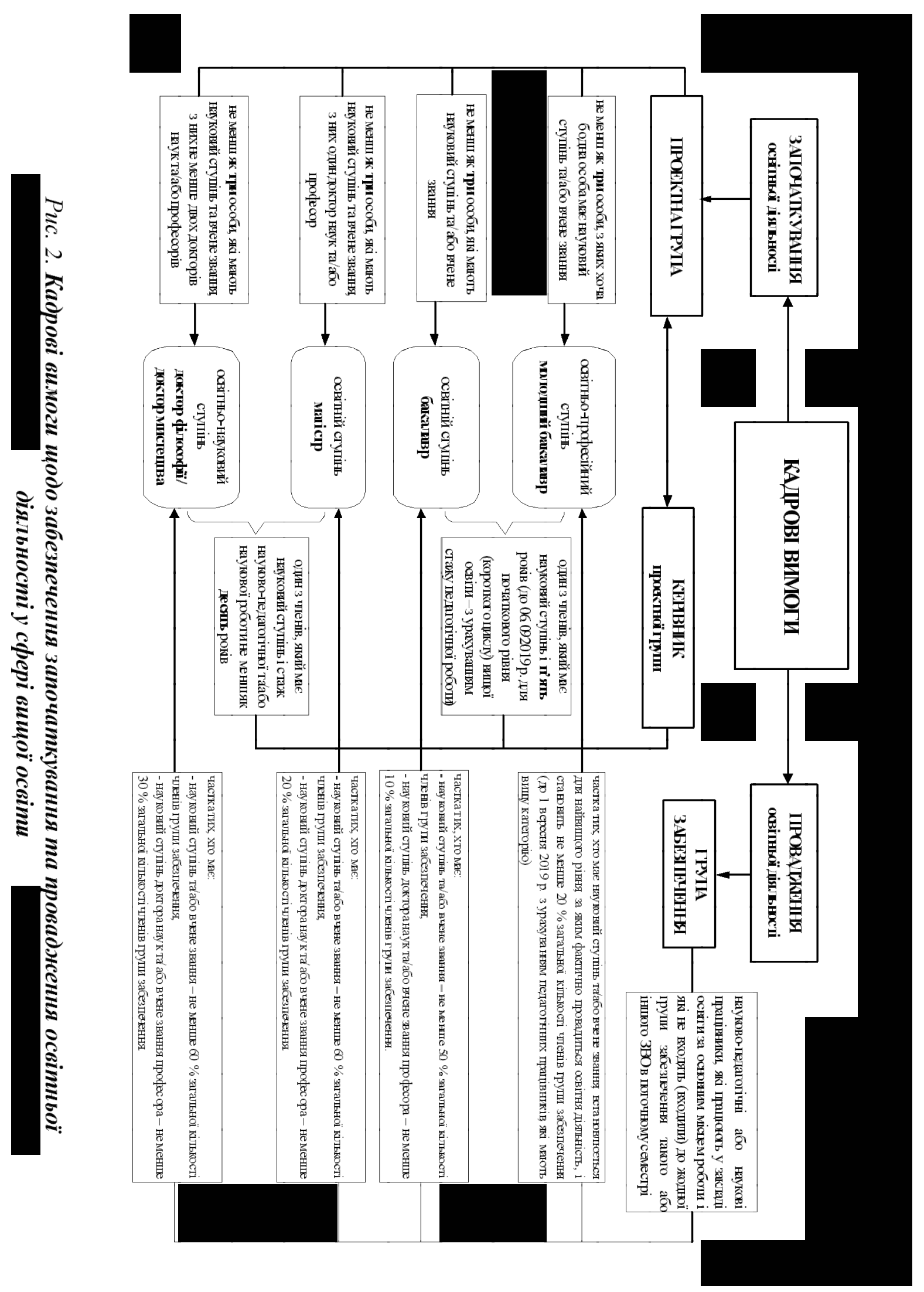


значається один з ії членів, який має науковий ступінь і стаж науково-педагогічної та/або наукової роботи не менш як десять років для освітньонаукового ступеня доктора філософії і ступеня магістра та п'ять років для освітніх ступенів бакалавра і молодшого бакалавра (до 6 вересня 2019 р. для початкового рівня (короткого циклу) вищої освіти - 3 урахуванням стажу педагогічної роботи). Керівник проектної групи не може в поточному навчальному році одночасно керувати іншими проектними групами, за винятком керівництва проектними групами за різними рівнями вищої освіти в межах однієї спеціальності в даному ЗВО.

Додаткові вимоги до керівника проектної групи щодо наявності в нього не менше однієї статті у періодичному виданні, яке включене до однієї 3 наукометричних баз, зокрема Scopus або Web of Science Core Collection, уводяться в дію з 2021 року [5].

Відповідно до чинного законодавства, залежно від рівня вищої освіти, до складу проектної групи відповідної спеціальності встановлюються такі вимоги для:

освітньо-професійного ступеня молодшого бакалавра у складі повинні бути не менш як три особи, 3 яких хоча б одна особа має науковий ступінь та/або вчене звання;

освітнього ступеня бакалавра у складі повинні бути не менш як три особи, які мають науковий ступінь та/ або вчене звання;

освітнього ступеня магістра у складі повинні бути не менш як три особи, які мають науковий ступінь та вчене звання, з них - один доктор наук та/або професор;

освітньо-наукового ступеня доктора філософії/доктора мистецтва у складі повинні бути не менш як три особи, які мають науковий ступінь та вчене звання, 3 них не менше двох докторів наук та/або професорів.

Група забезпечення спеціальності - це група педагогічних, науково-педагогічних та/або наукових працівників, для яких освітній заклад $\epsilon$ основним місцем роботи та мають кваліфікацію відповідно до спеціальності, які не входять (входили) до жодної групи забезпечення такого або іншого ЗВО в поточному семестрі [8]. Під час провадження освітньої діяльності у сфері вищої освіти група забезпечення відповідає за виконання освітніх програм однієї спец- іальності на певному рівні вищої освіти та особисто бере участь в освітньому процесі. При цьому склад групи забезпечення повинен відповідати таким вимогам:

частка тих, хто має науковий ступінь та/або вчене звання, установлюється для найвищого рівня, за яким фактично провадиться освітня діяльність, і становить не менше 20\% загальної кількості членів групи забезпечення для рівня молодшого бакалавра (до 1 вересня 2019 р. 3 урахуванням педагогічних працівників, які мають вищу категорію), 50\% - бакалавра, 60\% - магістра, доктора філоcoфiï;

частка тих, хто має науковий ступінь доктора наук та/або вчене звання професора, установлюється для найвищого рівня, за яким фактично провадиться освітня діяльність i становить не менше $10 \%$ загальної кількості членів групи забезпечення для рівня бакалавра, 20\% - магістра, 30\% - доктора філософії/доктора мистецтва [5;8].

Зазначимо, що кількість членів групи забезпечення є достатньою, якщо на одного іiі члена припадає не більше 30 здобувачів вищої освіти всіх рівнів, курсів та форм навчання 3 відповідної спеціальності (для дистанційної форми навчання не більше 60 здобувачів).

Усі педагогічні, науково-педагогічні та/або наукові працівники, які залучені до проектної групи та групи забезпечення спеціальності повинні мати кваліфікацію відповідно до спеціальності та виконувати не менше чотирьох видів та результатів професійної діяльності, які застосовуються до визнання кваліфікації відповідної спеціальності. Кваліфікація відповідно до спеціальності - це кваліфікація особи, підтверджена документом про освіту чи науковий ступінь із відповідної спеціальності або підтверджена науковою, науково-педагогічною, педагогічною чи іншою професійною діяльністю за відповідною спеціальністю за не менш як сімома видами чи результатами, переліченими в пункті 30 чинних Ліцензійних умов [5].

Зазначимо, що під час визначення рівня наукової та професійної активності науково-педагогічного (наукового) працівника можуть зараховуватися здобутки за попередніми місцями роботи; п'ятирічний строк може продовжуватися на час перерви в роботі з об'єктивних причин (соціальна відпустка, призов/мобілізація на військову службу чи військова служба за контрактом, тривала хвороба тощо).

Кадрові вимоги також включають наявність трудових договорів (контрактів) 3 усіма науково-педагогічними (науковими) працівниками та наказів про прийняття їх на роботу. Трудові договори (контракти) можуть бути відсутні лише для працівників, які прийняті на роботу до конкурсного заміщення вакантних посад у встановленому законодавством порядку або на умовах строкового договору без проведення конкурсу в разі заміщення посад працівників, які підвищують кваліфікацію або проходять стажування з відривом від виробництва, або перебувають у соціальній відпустці.

Таким чином, кожний 3ВО, який подає заяву про отримання ліцензії на провадження освітньої діяльності (розширення провадження освітньої діяльності) за спеціальністю на певному рівні вищої освіти, зобов'язаний забезпечити кадровий склад працівників відповідно до передбачених чинними Ліцензійними умовами вимог. На жаль, ЗВО не завжди можуть забезпечити виконання викладених вище вимог і стикаються із низкою проблем та дискусійних питань у сфері кадрового забезпечення освітньої діяльності, через що отримують відмову у проведенні ліцензування.

Так, опираючись на власний досвід, отриманий під час обгрунтування результатів проведених процедур ліцензування освітньої діяльності у сфері вищої освіти Національного університету "Львівська політехніка", узагальнено окремі дискусійні питання щодо кадрового забезпечення. Серед них:

заклад вищої освіти чи його відокремлений структурний підрозділ (філія) не забезпечує подання в електронному вигляді всіх даних та відомостей про кадрове забезпечення освітнього процесу до Єдиної державної електронної бази з питань освіти та не підтримує їх в актуальному стані;

особи, що входять до проектної групи чи групи забезпечення не відповідають за своєю кваліфікацією відповідно до диплому про вищу освіту чи науковий ступінь спеціальності, що ліцензується, та при цьому не виконують мінімум сім видів та результатів професійної діяльності; особи, що входять до проектної 
групи чи групи забезпечення не працюють за основним місцем роботи в 3ВО, що проходить ліцензування;

керівником проектної групи призначається особа, яка не має наукового ступеня, але відповідає спеціальності, що ліцензується за своєю освітою, або працює у ЗВО за сумісництвом;

стаж науково-педагогічної та/або наукової роботи керівника проектної групи не відповідає чинним Ліцензійним вимогам;

у складі проектної групи не відзначено, хто є її керівником та чи є він загалом;

за однією особою, що входить до складу групи забезпечення, закріпляють понад п'ять навчальних дисциплін;

під час формування складу групи забезпечення, при обчисленні часток тих, хто має наукові ступені та/ або вчені звання, зустрічаються помилки арифметичного або методичного характеру;

до складу групи забезпечення залучаються викладачі, котрі за своєю вищою освітою чи науковим ступенем не відповідають дисципліні, що за ним закріплена;

інформація про наукову діяльність (основні публікації за напрямом, науково-дослідною роботою, участю у конференціях і семінарах) кадрового складу проектної групи не відповідає спеціальності, що ліцензується;

відомості про підвищення кваліфікації викладача подаються не повною мірою (наприклад, не прописують найменування закладу, вид документа та дату видачі, а також тему, за якою викладач проходив підвищення кваліфікації);

Окрім наведених вище, зустрічаються й інші дискусійні питання щодо кадрового забезпечення започаткування та провадження освітньої діяльності відповідно до чинних Ліцензійних вимог.

Висновки та перспективи подальших досліджень. Таким чином, автором систематизовано та впорядковано кадрові вимоги щодо започаткування і провадження освітньої діяльності в процедурі ліцензування у сфері вищої освіти відповідно до чинних Ліцензійних вимог. На основі власного досвіду узагальнено окремі дискусійні питання щодо кадрового забезпечення під час проходження процедури ліцензування освітньої діяльності у сфері вищої освіти.

Зазначимо, що проблеми у виконанні кадрових вимог Ліцензійних умов щодо надання освітніх послуг у сфері вищої освіти з'являються тому, що заклади вищої освіти не мають достатнього кількісного та якісного складу педагогічних, науково-педагогічних та/або наукових працівників 3 науковими ступенями та вченими званнями. Вирішення цієї проблеми $\epsilon$ першочерговим завданням майже кожного ЗВО України.

Надалі автором планується продовжувати досліджувати ліцензійноакредитаційну систему забезпечення якості вищої освіти України та іï особливості.

\section{ЛІТЕРАТУРА}

1. Бахрушин В. Ліцензування освітньої діяльності - куди рухаємося? [Електронний документ] / Точка зору. Освітня політика. Портал громадських експертів. 13.08.2015. URL: http:// education-ua.org/ua/articles/465litsenzuvannya-osvitnoji-diyalnostikudi-rukhaemosya.

2. Про адміністративні послуги: Закон України. URL: https:// zakon4.rada.gov.ua/laws/show/520317.

3. Про вищу освіту: Закон України від 1 липня 2014 р. № 1556-VII. URL: https://zakon.rada.gov.ua/laws/show/ 1556-18/ed20150529.

4. Про ліцензування видів господарської діяльності : Закон України. URL: http://zakon3.rada.gov.ua/laws/ show/222-19/print1464684563806810.

5. Про внесення змін до постанови Кабінету Міністрів України від 30 грудня 2015 р. №1187. Постанова Кабінету Міністрів України від 10.05.2018 p. № 347

6. Про затвердження Ліцензійних умов провадження освітньої діяльності закладів освіти. Постанова Кабінету Міністрів України від 30.12.2015 p. № 1187.

7. Рябчій В. А. Аналіз реалізації акредитаційних вимог щодо кадрового забезпечення навчального процесу тези доповідей наук.-практ. конф. Управління якістю підготовки кадрів з вищою освітою через удосконалення процедур ліцензування, акредитації та рейтингування:
Дніпропетровськ, 15-16 березня 2012 p. C. $238-240$.

8. Шевцов А. Г. Ліцензування поновому: про особливості нових Ліцензійних умов провадження освітньої діяльності закладів освіти. Освіта України. 2018. № 21.29 трав. С. 8.

\section{REFERENCES}

1. Bakhrushin V. Licensing of Educational Activities - Where are We Moving? / Point of view. Educational policy. Portal of Public Experts. 08/13/ 2015. URL : http://education-ua.org/ua/ articles/465-litsenzuvannya-osvitnojidiyalnosti-kudi-rukhaemosya.

2. On Administrative Services: Law of Ukraine. URL : https:// zakon4.rada.gov.ua/laws/show/520317.

3. Law of Ukraine: On Higher Education dated July 1, 2014 No. 1556VII. URL : https://zakon.rada.gov.ua/ laws/show/1556-18/ed20150529.

4. On Licensing Types of Economic Activity: Law of Ukraine. URL : http:// zakon3.rada.gov.ua/laws/show/222-19/ print1464684563806810.

5. On Amendments to the Resolution of the Cabinet of Ministers of Ukraine dated December 30, 2015 № 1187. Resolution of the Cabinet of Ministers of Ukraine dated May 10 , 2018. № 347.

6. On Approval of Licensing Conditions for Conducting Educational Activities of Educational Institutions. Resolution of the Cabinet of Ministers of Ukraine dated December 30, 2015 № 1187.

7. Ryabchy V. A. Analysis of the implementation of accreditation requirements for personnel training in the educational process. Quality management of personnel training with higher education through improvement of licensing, accreditation and rating procedures $\therefore$ theses of the reports of the scientific and practical conference. Dnipropetrovsk. March 15-16, 2012. P. 238-240.

8. Shevtsov A. G. Licensing in a new way: about the features of the new Licensing Conditions for the Educational Activities of Educational Institutions // Education of Ukraine. 2018. № 21. May 29. P. 8.

Стаття надійшла 27.02.2019 р. 